Article

\title{
Combined Use of 3D Metric Survey and GPR for the Diagnosis of the Trapezophoros with Two Griffins Attacking a Doe of Ascoli Satriano (Foggia, Italy)
}

\author{
Marilena Cozzolino ${ }^{1, *(\mathbb{D}}$, Andrea Di Meo ${ }^{1}$, Vincenzo Gentile ${ }^{1}$, Paolo Mauriello ${ }^{1}$ and \\ Enza Zullo ${ }^{2}$ \\ 1 Department of Human, Social and Educational Science, University of Molise, Via De Sanctis, \\ 86100 Campobasso, Italy; andrea.dimeo@studenti.unimol.it (A.D.M.); vincenzo.gentile86@gmail.com (V.G.); \\ mauriello@unimol.it (P.M.) \\ 2 Superintendence of Archeology, Arts and Landscape for the provinces of Foggia and Barletta, Andria, Trani, \\ Via Alberto Valentini Alvarez 8, 71121 Foggia, Italy; enza.zullo@beniculturali.it \\ * Correspondence: marilena.cozzolino@unimol.it
}

Received: 28 May 2020; Accepted: 30 June 2020; Published: 9 August 2020

check for updates

\begin{abstract}
Protection and conservation are not feasible without a deeper knowledge of the cultural heritage of the subject of intervention. A careful analysis of documentation, a detailed visual inspection of surfaces, and a systematic diagnosis of the inner properties are the basis for planning preventive strategies of restoration. Digital noninvasive techniques represent an advantageous tool with useful outputs to estimate the state of health of cultural heritage in order to minimize the progress of degradation. This paper deals with a 3D metric survey through photogrammetry and ground-penetrating radar (GPR) tests applied to the study of the trapezophoros with two griffins attacking a doe of Ascoli Satriano, a masterpiece of ancient art that needs to be protected. This work provided information on both visible and hidden defects, such as numerous cracks that affect the sculpture.
\end{abstract}

Keywords: trapezophoros of Ascoli Satriano; 3D digital metric survey; GPR; diagnosis pre-conservation

\section{Introduction}

The trapezophoros with two griffins attacking a doe (Figure 1) was found in the 1970s through illegal excavations in the territory of Ascoli Satriano (Foggia, Italy). It represents a supporting ritual table (325-300 B.C.) realized using an oriental marble probably coming from Aphrodisias di Caria $[1,2]$ p. 4 .

It is probably part of the remains of princely funeral equipment placed in a chamber tomb, made in the typical shapes and sizes of the funerary costume of the Daunian communities during the 4th century B.C. [2] p. 1. This is suggested by the relatively good state of conservation, the link with other artifacts in marble discovered in the same place, and the analogy with a similar table with a function of support for offerings found in the monumental hypogeum Lagrasta I of Canosa [3].

The sculpture, $0.95-\mathrm{m}$-high and 1.48-m-long, consists of a pair of griffins, each with a lion's body and a dragon's head with a crest on the head and wings spread upwards. They are in hunting action while grasping with claws a doe on the ground that emerges with its snout lying on the ground with its front legs folded and its rear ones fully extended. The subject is present with similar iconography in the clay appliques from Taranto $[4,5]$ and was reproduced in one of the painted bands that decorates the Kline A, a mortuary bed of the Macedonian tomb of Potidea [6]. 


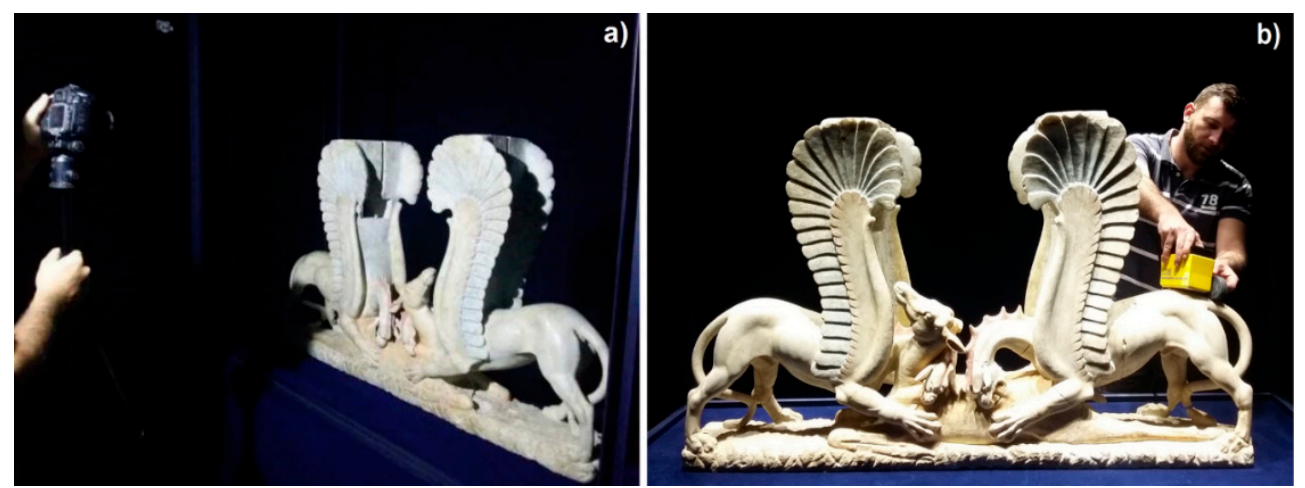

Figure 1. The acquisition of images with a reflex Nikon D80 (a) and a ground-penetrating radar (GPR) survey with an IDS-RIS K2 instrument equipped with a 1200-MHz antenna (b).

One of the main elements of interest of the artefact is represented by the pictorial decoration characterized by the presence of six different colors [2] pp. 4-5: in pink, the engraved lines of the attachment of the plumage to the body of the griffins and inside the nostrils, in yellow-beige, the body of the griffins and the internal curvature of the edge of the wings, in bright yellow, the doe, in red, the crests of the griffins and the blood of the bitten doe that flows from their jaws, in blue, the wings, in white, the deep groove of the feathers, and, in green, the rocky base.

The sculpture and the artifacts found together with it have had a troubled history [1,7-9]. Grave robbers sold the trapezophoros to the art dealer G. Medici, and it later ended up, through the international trafficker R. Symes, in the collection of the Belgian-American diamond merchant and mining magnate M. Tempelsman. Subsequently, it was sold to the J. Paul Getty Museum in Malibu, California. After long negotiations conducted by the Italian Ministry for Cultural Heritage, 22 years after the purchase was made in 1985, the finds were returned to Italy on 1 August 2007. In June 2010, the Ministry authorized the return home of the extraordinary objects that are currently conserved at the Museum Complex of Ascoli Satriano [10].

Today, the trapezophoros is affected by important instability phenomena highlighted by many superficial lesions. No document concerning its cracked state has been produced so far. Given the important need to preserve it and the lack of a complete reading of its state of health, a highly detailed diagnostic study was realized in the form of a collaboration between the Superintendence of Archeology, Arts and Landscape for the provinces of Foggia and Barletta-Andria-Trani and the University of Molise.

A geophysical diagnosis represents a well-known tool to achieve the identification, protection, preservation, enhancement, and fruition of Cultural Heritage [11]. Within this contest, various techniques are commonly applied to search for potential buried archaeological targets and to analyze architectural heritage and historic structures [12-30]. In recent years, the use of geophysics for the diagnostics and monitoring of the health statuses of structures, surfaces of archaeological monuments, and manmade artifacts has largely increased because of the improved need to investigate cultural heritage features in a noninvasive way. In this framework, ultrasound, vibration-based methods, linear variable displacement transducer (LVDT), synthetic-aperture radar (SAR), thermography, and ground-penetrating radar (GPR) are often employed because of the nondestructive features of the applications and the high resolution of the results [11,31-42]. For overall analyses of an artifact, the diagnostic methods are often qualitatively and quantitatively integrated with 3D metric surveys (photogrammetry and laser scanner), gathering information on external and inner signs of deterioration [43-51].

For this purpose, the following workflow was adopted in the study of the trapezophoros: 
1. The creation of a high-resolution 3D model and orthophotos of the external surfaces through a photogrammetry digital survey (Figure 1a) in order to highlight the decay and even the type, which is not perceivable by direct sight.

2. An analysis of the inner surfaces through the implementation of noninvasive GPR surveys (Figure 1b), with the purpose of detecting anomalies and possibly indicating voids or fractures.

3. The production of new and detailed documentation, which has been nonexistent so far and which is useful for planning future conservation actions.

\section{Materials and Methods}

\subsection{Photogrammetric Digital Survey}

The survey was performed by acquiring about 500 photos, ensuring a mean overlap of about $80 \%$ using a reflex Nikon D80 camera equipped (Figure 1a) with a CCD (charge-coupled device) sensor $(23.6 \times 15.8 \mathrm{~mm})$, with 12.2 million pixels and a fixed focal length of $24 \mathrm{~mm}$. The images were captured in RAW format, setting the camera in aperture priority mode (value f/9) and an ISO value of 100.

Agisoft Photoscan software was used for data processing using the following steps:

- Frame alignment through the Structure-from-Motion (SfM) technique [52,53]. A sparse point cloud consisting of 308,196 points that describes the object's geometry (Figure 2a), and the camera positions at the frame captures were obtained using the "medium alignment" (key point limit: 40,000 and tie point limit: 4000).

- Construction of the geometry through dense cloud portrayed by 5,720,932 points (Figure 2b) using the "medium build dense cloud" settings.

- Mesh production in which the point cloud was transformed onto a surface consisting of 380,785 triangulated dots (Figure 2c-e). In order to recognize and fit discontinuities on the model, the "multiresolution model" routine based on automated algorithms was used [54]. Furthermore, the "optimization method" and the "decimation filter" were applied for rearranging and smoothing, respectively, the nodes of the triangles and for simplifying the model and generating a multiresolution model.

- $\quad$ Positioning the 3D model in Cartesian space in real metric units with a total station. The coordinates of the topographic survey were introduced, placing ground control point (GCP) markers on each frame, which exist in multiple images, obtaining an average registration error relative to the entire photogrammetric survey of about $3 \mathrm{~mm}$ (Figure 2f).

- Construction of the texture through the application of the photographic images to the 3D digital model (Figures $2 \mathrm{f}$ and 3 ). The "generic mapping mode" was used to create a texture as uniform as possible, and the "mosaic blending mode" was used for avoiding seam line problems and for blending low and high-frequency components regarding overlapping images.

- Creation of orthophotos of the visible surfaces with a resolution of $1.56 \mathrm{~mm} /$ pix (Figure 4).

\subsection{GPR Survey and Data Processing}

An IDS georadar RIS-K2 with a 1200-MHz high-resolution antenna was used for data acquisition. The survey was designed, taking into account the complex surface of the sculpture, and 26 profiles with varying lengths were acquired (Figure 5). Technically, data acquisition took place on lines, sometimes with a curvilinear shape, where instrumental readings were executed in continuous mode using marks to signify changes in the surface levels. 


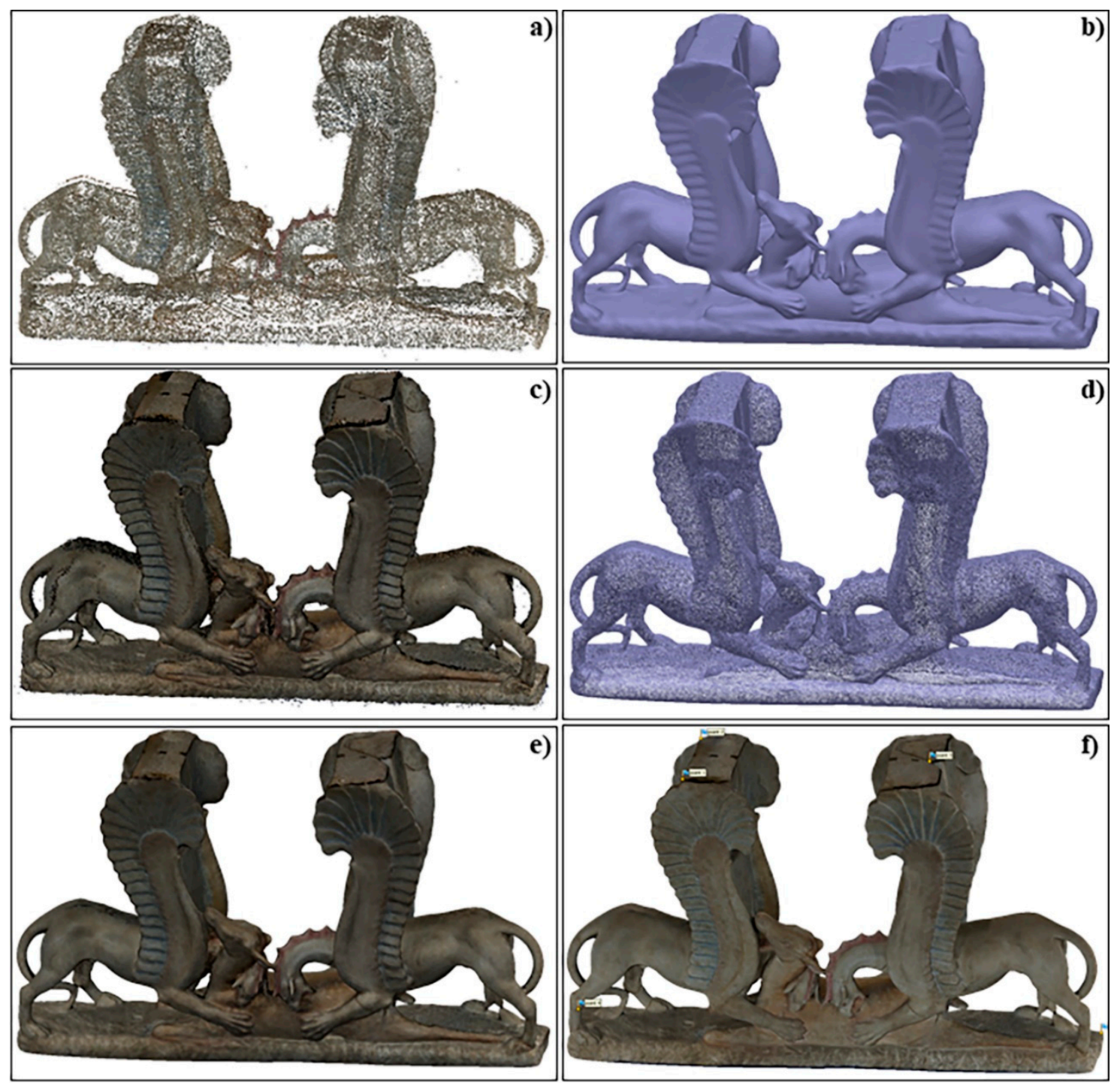

Figure 2. Sparse point cloud (a), dense cloud (b), mesh RGB (c), solid mesh (d), wireframe mesh (e), and texture with ground control points (GCPs) (f).

Raw data were processed using GPR-SLICE 7.0 software [55] using standard methodological approaches. In the first step, data and trace editing was executed, inserting information such as the temporal and spatial sampling intervals (time window, $40 \mathrm{~ns}$, samples/scan, 512, scan/mark, 25, and unit/marker, 1). Data were recorded and processed as 16-bit data and were converted, subtracting out the dc-drift (wobble) in the data and, at the same time, adding a gain with a time of 20. A time-zero correction was determined to designate the starting point of the wave (27), and the center frequency $(1212 \mathrm{MHz})$ of the antenna was matched. 

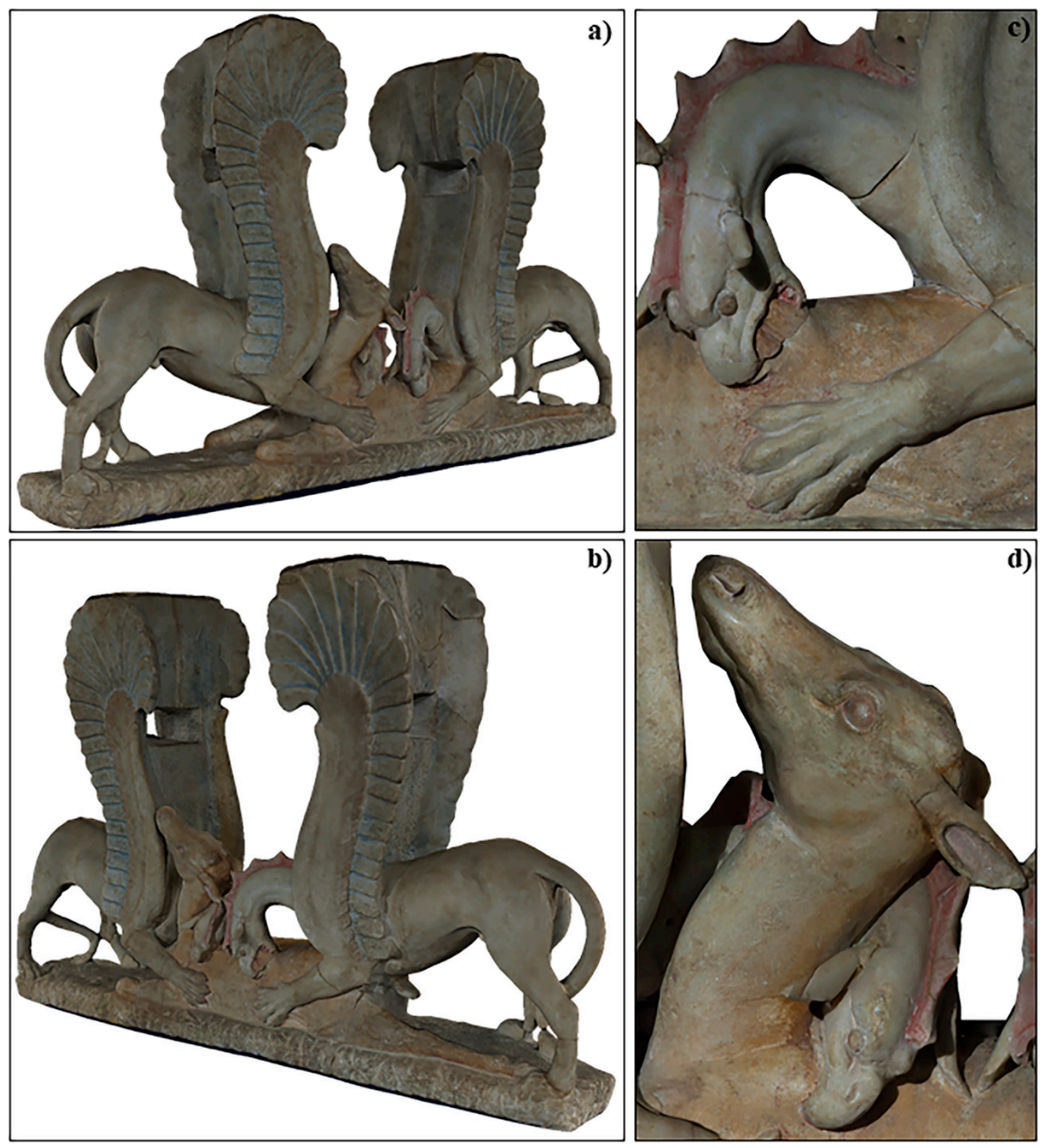

Figure 3. High-resolution 3D model: front (a) and back view (b) and two details of the sculpture (c,d).

Then, a bandpass filter and background removal were respectively applied to reduce noise from the oscillating components that had a regular frequency cycle in the frequency domain (low cutoff: $383 \mathrm{MHz}$ and upper cutoff: $3212 \mathrm{MHz}$ ) and to remove striation noises that occurred at the same time.

Processed radargrams were subsequently corrected with an automatic gain control (ACG) function [56] applied to each trace based on the difference between the mean amplitude of the signal in the time window and the maximum amplitude of the trace.

The depth of the reflectors was approximately derived considering a velocity of $11 \mathrm{~cm} / \mathrm{ns}$, which is typical for marble, the material of which the sculpture was made. This supposition was confirmed by fitting the hyperbolas in radargrams $1,2,3$, and 26, which allowed for the definition of the same average velocity and a relative dielectric permeability of 7.44 to be compatible with the material under analysis. Using these parameters, the migration time domain method (Kirchoff migration) was finally applied to obtain a focused image of the underground objects. We avoided further processing of the 
data with other algorithms by introducing additional estimated parameters with the possibility of obtaining an arbitrary and inaccurate evaluation of targets.

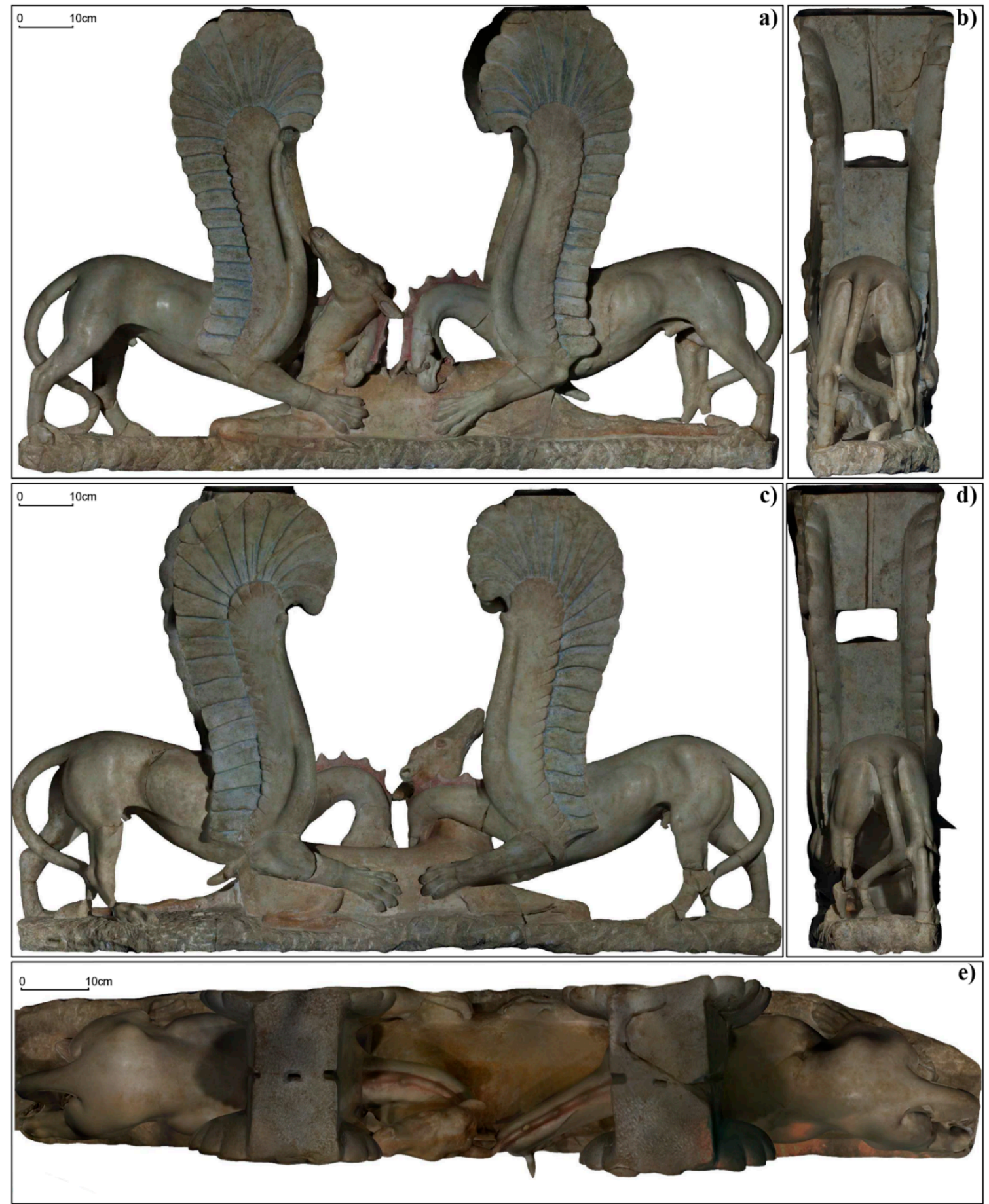

Figure 4. High-resolution orthophoto: front side (a), back side (b), right side (c), left side, (d) and top (e).

Following [57,58], the vertical resolution was taken to be between $0.45 \mathrm{~cm}$ and $0.225 \mathrm{~cm}$, and the horizontal resolutions, at depths equal to $2 \mathrm{~cm}, 4 \mathrm{~cm}, 6 \mathrm{~cm}, 8 \mathrm{~cm}$, and $10 \mathrm{~cm}$ from the ground surface to the reflection surface where the antenna footprint was calculated, were estimated to be $0.518 \mathrm{~cm}$, $0.587 \mathrm{~cm}, 0.656 \mathrm{~cm}, 0.725 \mathrm{~cm}$, and $0.795 \mathrm{~cm}$, respectively. These parameters were considered sufficient and suitable for an overall assessment of the conservation status of the statue with respect to the type 
of target to be investigated and the thicknesses of the surfaces to be analyzed. We may have to use higher resolution devices for further information if requested by the restoration experts.

Even though a high-resolution topography was obtained by the 3D digital survey, a correction of distortions in the processed radargrams was not produced, as the main objective of the investigation - namely, the verification of the presence of internal fractures-was sufficiently achieved, albeit with an approximation, by analyzing the rectangular 2D pictures (profiles).
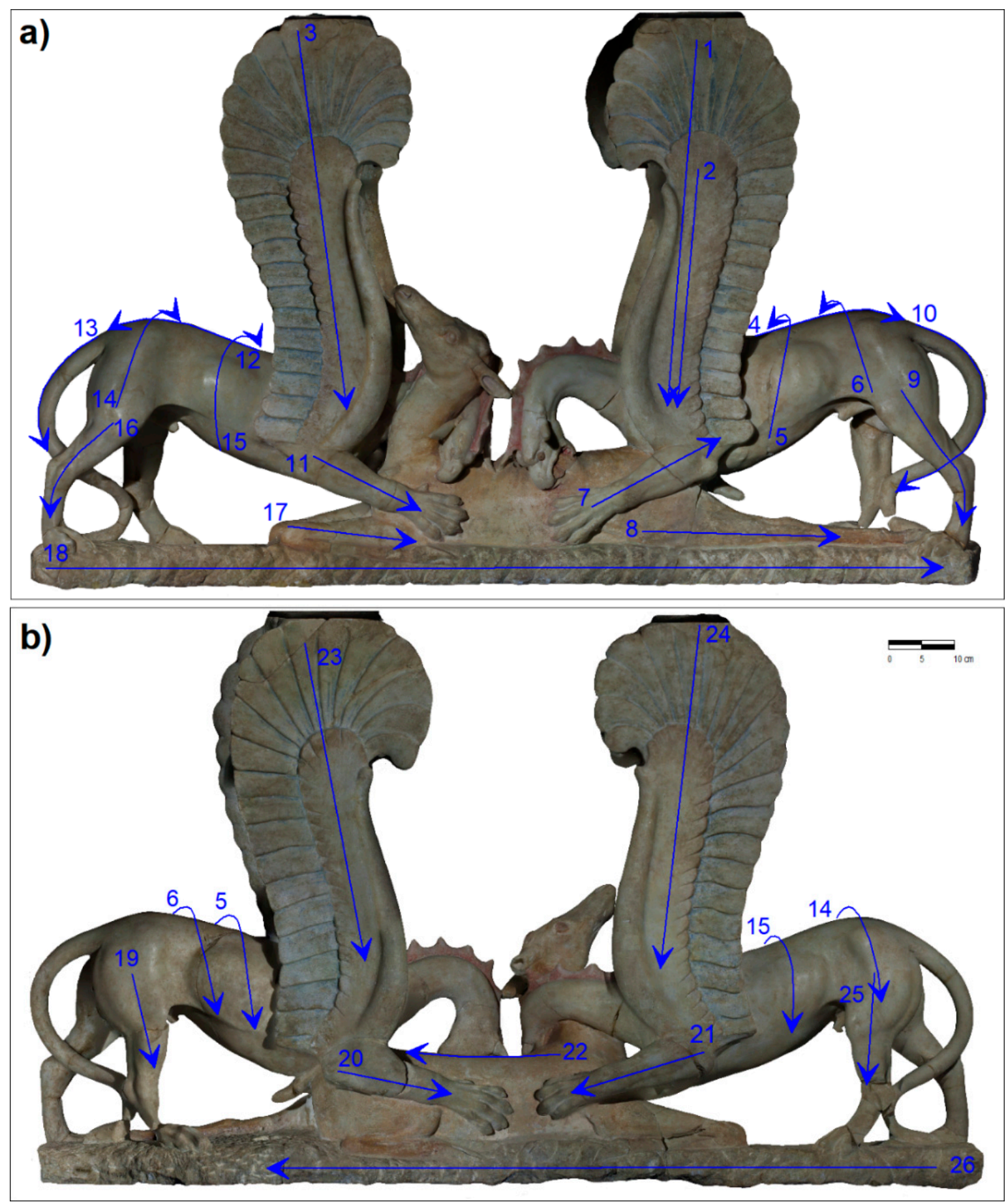

Figure 5. Location of ground-penetrating radar (GPR) data profiles in the frontal (a) and back (b) parts of the trapezophoros. 


\section{Results}

The visual analysis of the high-resolution orthophoto allowed for the detection of every single fracture, mapping 61 microlesions (magenta color) and portions characterized by the absence of marble (green color) (Figure 6).

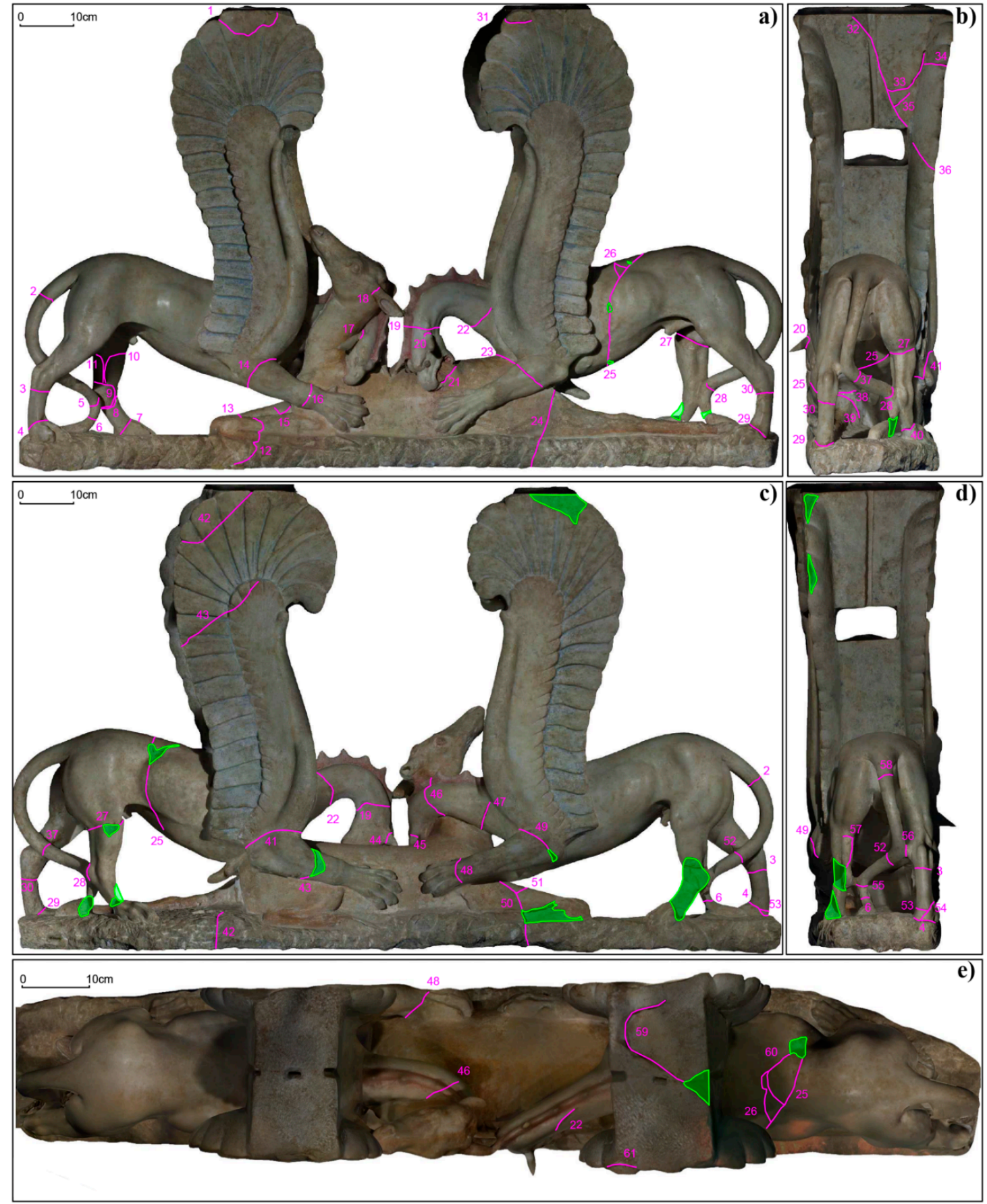

Figure 6. High-resolution orthophoto with indications of cracks: front side (a), back side (b), right side (c), left side $(\mathbf{d})$, and top $(\mathbf{e})$.

Fractures that differed in size, thickness, and orientation could be divided into three types: 
- Type 1: oblique and subvertical fractures with an average thickness of greater than $1 \mathrm{~mm}$ and, in some cases, up to $3 \mathrm{~mm}$. The fractures $4,5,7-12,14-18,21-25,28,29,32,33,35,36,39,42-44$, $46-50,52,54$, and 56 are part of this class.

- Type 2: sub-horizontal fractures with an average thickness of greater than $1 \mathrm{~mm}$, such as lesions $1-3,6,19-20,27,30,31,34,38,40,41,45,51,53,55$, and 58.

- Type 3: composite fractures that are characterized by the union or intersection of the types mentioned above, such as cracks 9-11, 26, 57, 59, and 60. They have an average thickness greater or equal to $1 \mathrm{~mm}$.

Figure 7 shows the details of the most significant microlesions, as follows:

- Fracture 25 (Figure 7a,g), which develops transversely to the body of the right griffin (type 1, $>1 \mathrm{~mm})$,

- Fracture 22 (Figure $7 \mathrm{~b}$ ), which affects the neck of the griffin on the right (type 1, >1 mm),

- Fracture 24 (Figure 7c), which cuts transversely across the hind legs of the doe and the base of the support of the sculpture (type $1,>2 \mathrm{~mm}$ ),

- Fracture 49 (Figure 7d), which develops transversely to the left front leg of the left griffon (type 1, $>2 \mathrm{~mm})$,

- Fracture 23 (Figure 7e), which is present on the left front leg of the right griffon and on the back of the doe (type $1,>1 \mathrm{~mm}$ ), and

- Fracture 27 (type 2, $>2 \mathrm{~mm}$ ), which cuts transversely the right rear leg of the right griffin (Figure 7f).
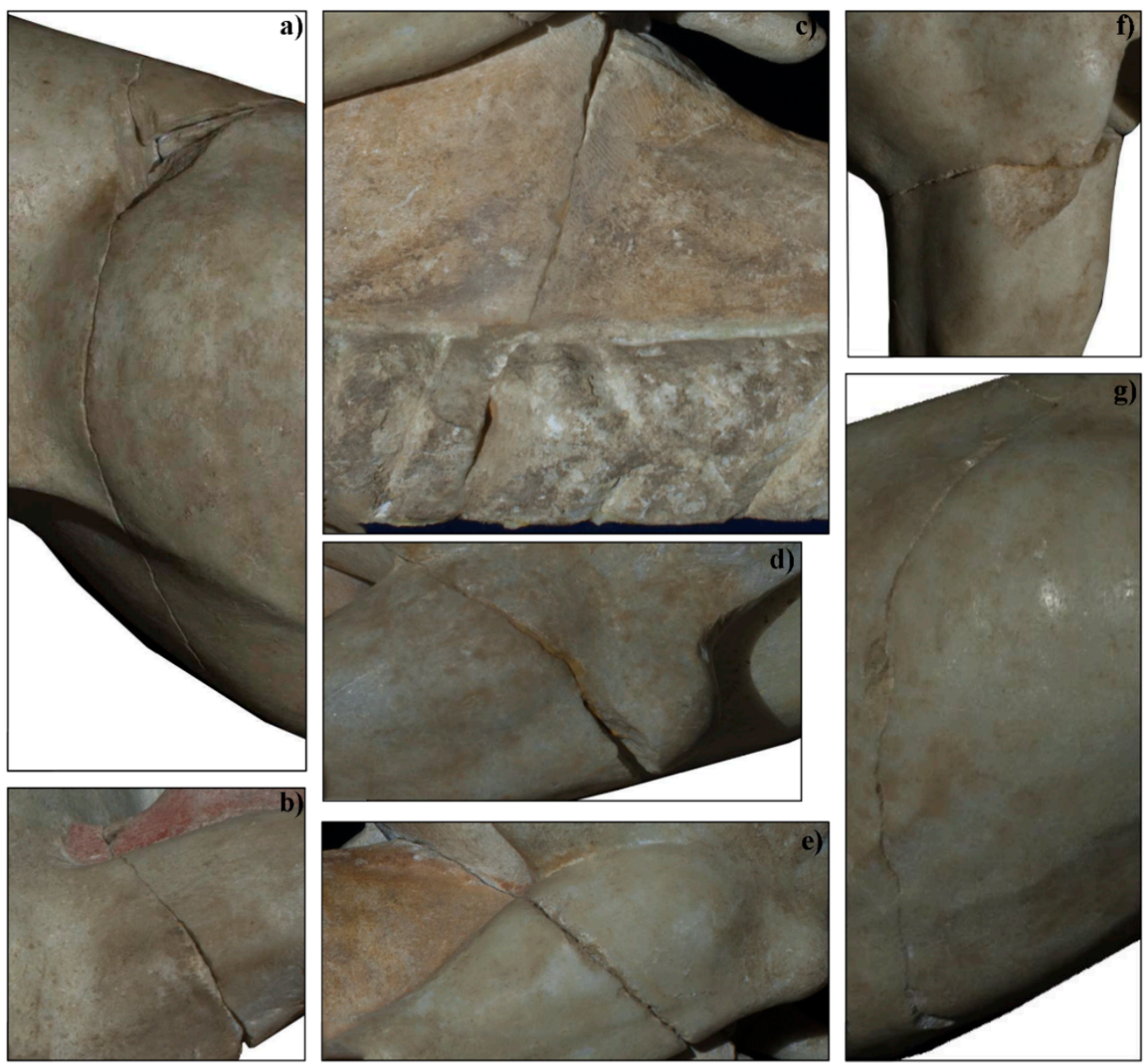

Figure 7. Details of the most significant microlesions $(\mathbf{a}-\mathbf{g})$. 
The general crack pattern appears very complex, and the most critical conditions concern the bodies of the griffins (in particular, the legs) and the head of the doe and griffins (in particular, the ears) (Figure 8).

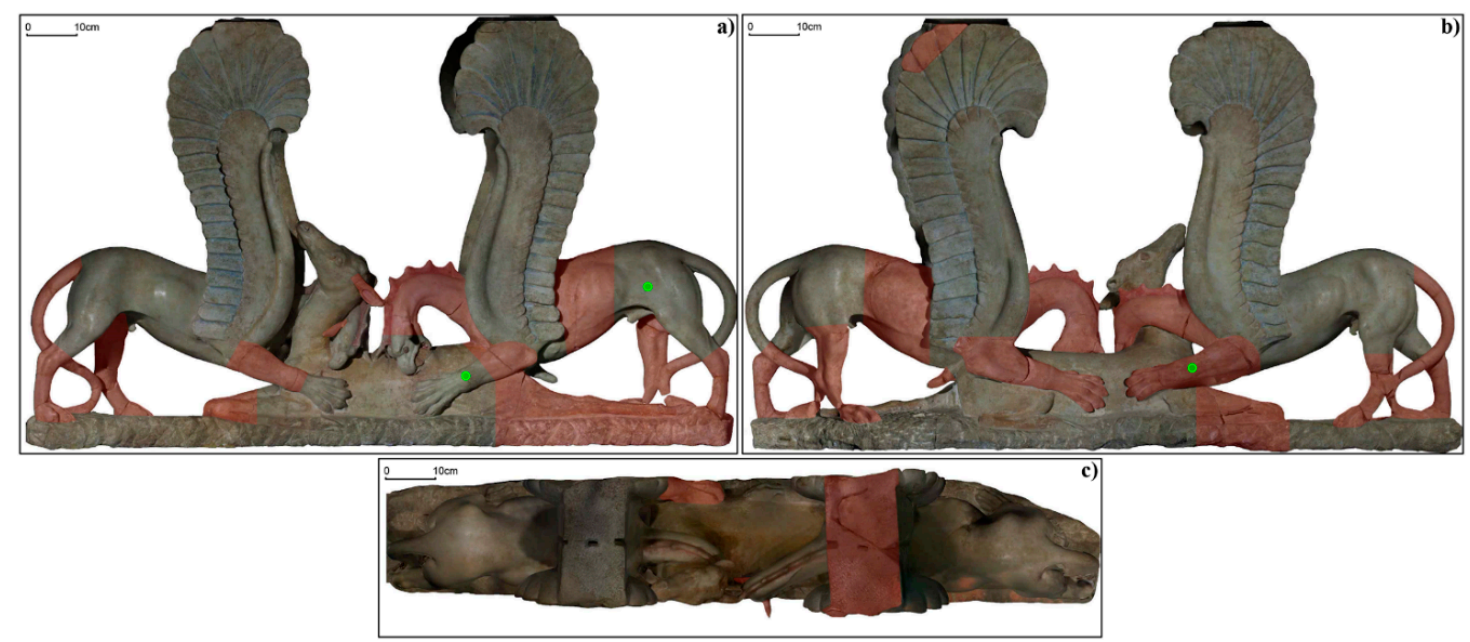

Figure 8. Indication of the more vulnerable areas of interest by the cracking phenomena: front side (a), back side (b), and top (c).

As regards the GPR investigation, Figures 9-11 display the obtained filtered and migrated radargrams. The analysis of the results was conducted for each individual profile, marking any anomalous signs with colored arrows.

Blue arrows were used to indicate the anomalies corresponding to lesions classified through visual analysis in profile 4 (fracture 26), profile 5 (fractures 25 and 26), profile 6 (fracture 26), profile 7 (fracture 23), profile 8 (fracture 24), profile 9 (fracture 30), profile 10 (fracture 37), profile 11 (fractures 14 and 16), profile 16 (fracture 3), profile 17 (fracture 15), profile 20 (fracture 43), and profile 21 (fractures 48 and 49).

Red arrows in profiles 1, 2, 3, 23, and 24 were used to indicate the anomalies due to air cavities defined by the rectangular tubes crossing the statue in the largest dimension, as seen in Figure 6c. They correspond to the holes for inserting the base of the table.

Green arrows were used to mark anomalies that did not coincide with elements identified by visual inspection and, thus, represented new elements relative to inner irregularities. In particular, three further probable internal fractures were detected in profiles 6, 7, and 21, the locations of which (indicated with green circles) are shown in Figure 8. On the contrary, the anomalies observed in profiles 18 and 26 seemed to be of greater magnitude and could be explained by air-filled cavities due to the large reflection coefficient, such as anomalies in profiles 1,2,3,23, and 24. The dimensions and the regularity with which they are distributed along the base of the statue suggest specific cavities created during the sculpting, the functions of which can be linked to the insertion of reinforcement or support elements.

Profiles 12, 13, 14, 15, 22, and 25 did not show significant anomalies.

The radargrams showed that most of the lesions are superficial and are located in the first $2 \mathrm{~cm}$ of the investigated surfaces. The only exceptions are the anomalies detected in profiles 18 and 26, which reach maximum depths of about $9 \mathrm{~cm}$. 


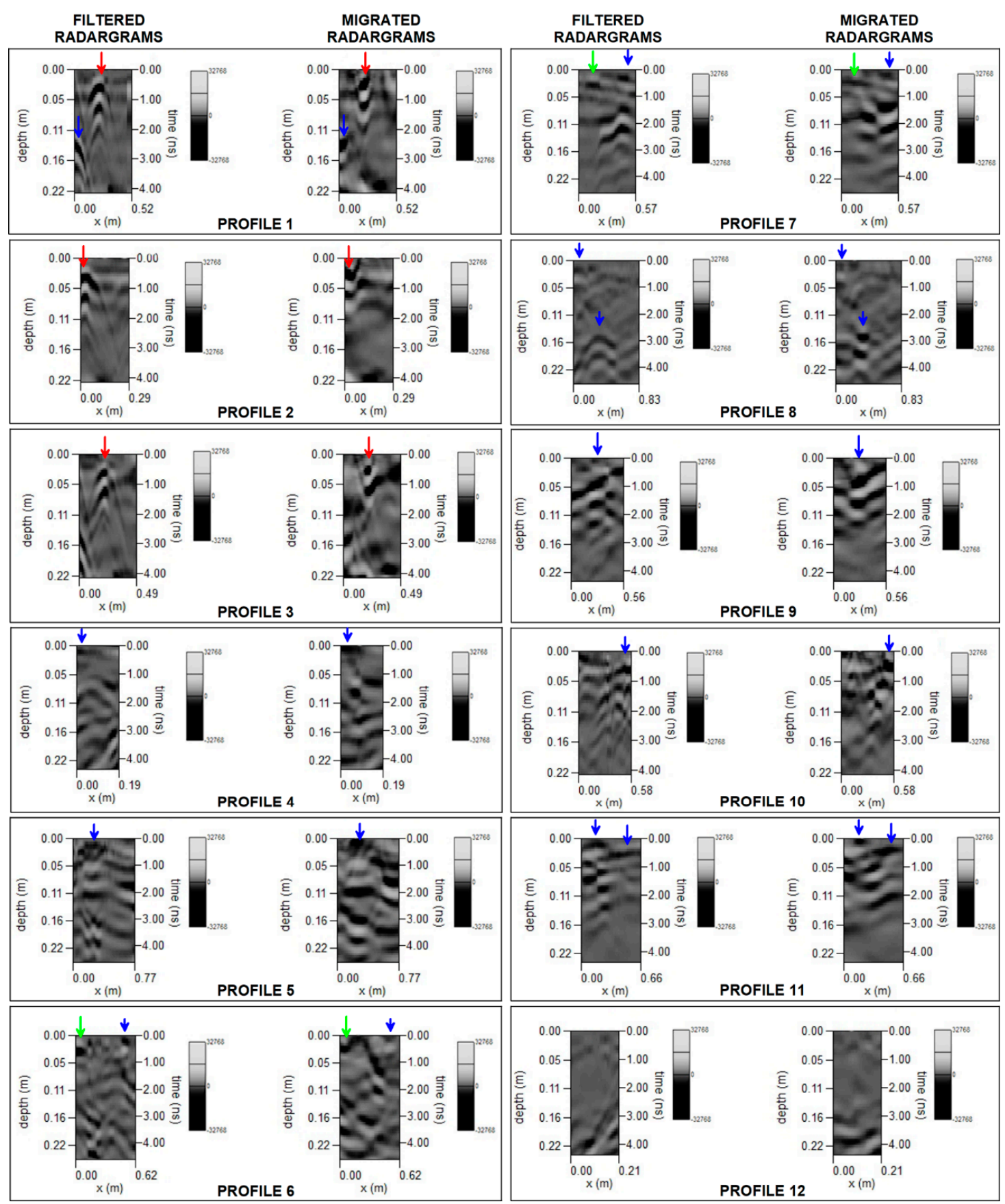

Figure 9. Filtered and migrated radargrams of profiles 1-12. 


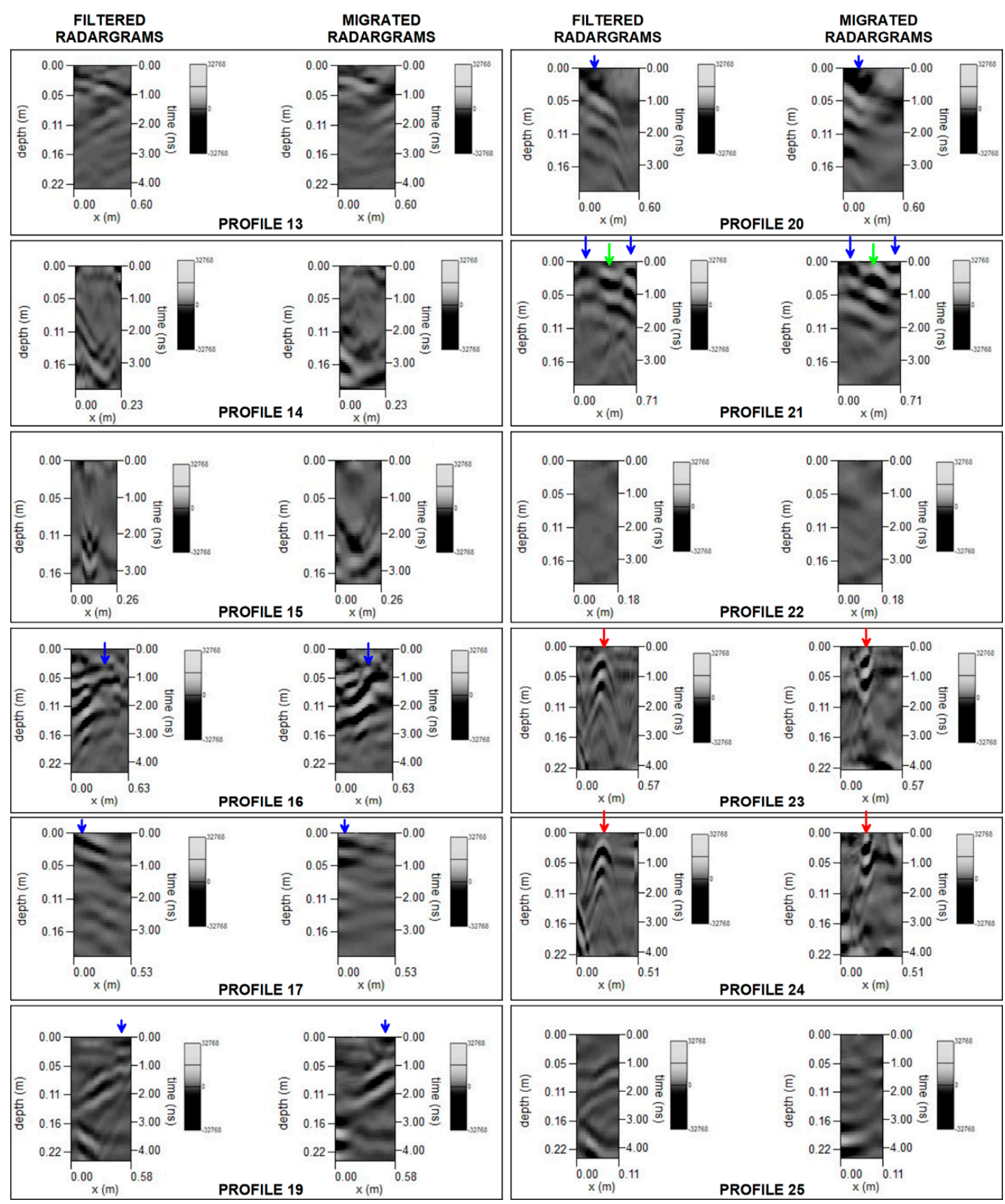

Figure 10. Filtered and migrated radargrams of profiles 13-17 and 19-25. 


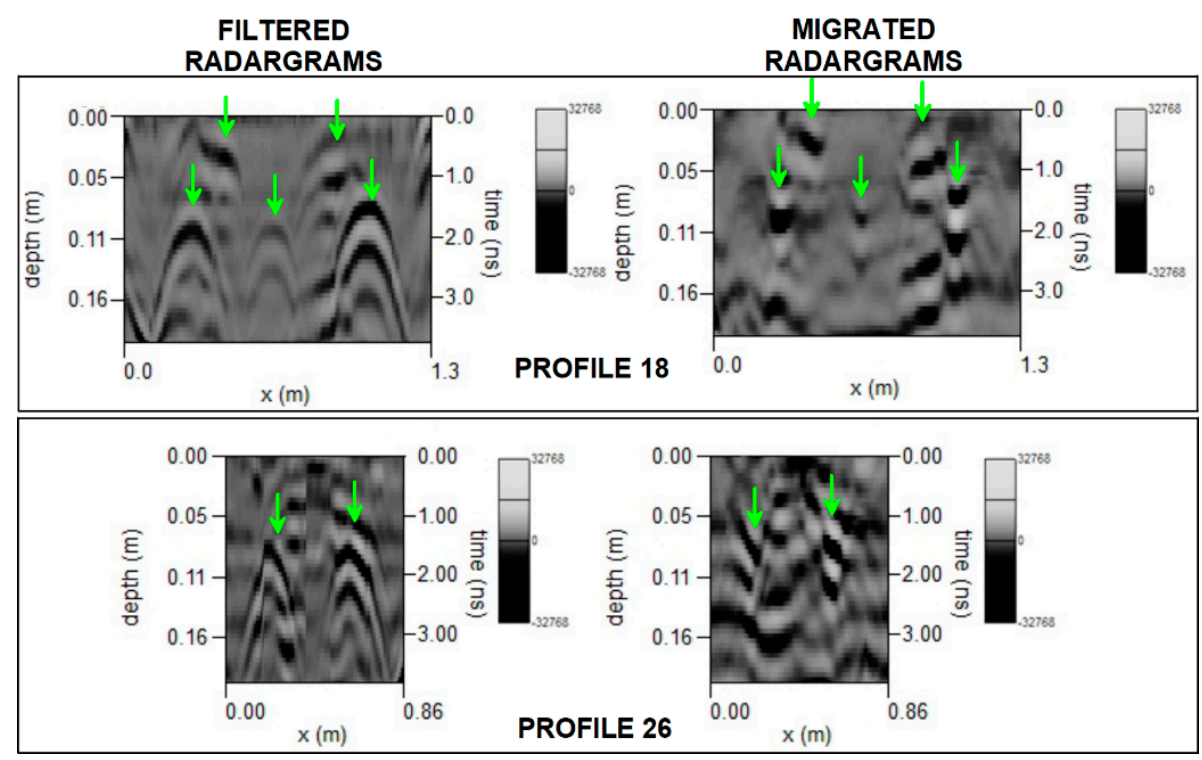

Figure 11. Filtered and migrated radargrams of profiles 18 and 26.

\section{Conclusions}

The combined use of a 3D metric survey and GPR analysis has allowed knowledge about the state of the health of the trapezophoros to be enriched, gathering new detailed documentation that has not existed so far.

The creation of a high-resolution 3D model and the extraction of detailed orthophotos of the external surfaces through a photogrammetry digital survey was useful to document each sign of decay, even the type that was not perceivable by direct sight, and GPR radargrams showed their inner extents, allowing three new probable fractures to be identified. The acquisition of continuous data on such a small and unusual curved surface was a great challenge, and the results produced relevant outputs.

Given the extent of cracking regarding above all the more fragile parts of the irregular sculpture, a careful plan of consolidation and restoration is needed to avoid further damage and the irreversible loss of a portion of it.

Author Contributions: Conceptualization, M.C. and P.M.; data curation, M.C., A.D.M., and V.G.; formal analysis, M.C. and P.M.; investigation, M.C., A.D.M., and V.G.; methodology, M.C. and P.M.; project administration, P.M. and E.Z.; supervision, M.C., P.M., and E.Z.; writing—original draft, M.C., V.G., P.M., and E.Z.; and writing-review and editing, M.C. and P.M. All authors have read and agreed to the published version of the manuscript.

Funding: This research received no external funding.

Acknowledgments: Special thanks to the Museum Complex of Ascoli Satriano, the Municipality of Ascoli Satriano, the Superintendence of Archeology, Arts, and Landscape for the provinces of Foggia and Barletta-Andria-Trani for the fruitful collaboration during the research activities.

Conflicts of Interest: The authors declare no conflict of interest.

\section{References}

1. Ghetti, L.M. (Ed.) Capolavori Dell'archeologia: Recuperi, Ritrovamenti, Confronti; Gangemi Editore spa: Roma, Italy, 2013.

2. Bottini, A.; Setari, E. Il complesso di marmi da Ausculum. In Il Segreto di Marmo. I Marmi Dipinti di Ascoli Satriano; catalogo della mostra Il segreto di marmo, Museo Nazionale Romano, 16 dicembre 2009-18 aprile 2010, Roma; Bottini, A., Setari, E., Eds.; Electa: Milano, Italy, 2009.

3. Cassano, R. (Ed.) Principi, Imperatori, Vescovi-Duemila Anni di Storia a Canosa; catalogo della mostra di Bari; Marsilio Editore: Venezia, Italy, 1992; pp. 206, 218.

4. Bentz, M. Eine Weihung von Reliefgefäßen im Diana-Heiligtum am Nemi-See. Boreas 1998, 21, 185-196. 
5. Lullies, R. Vergoldete Terrakotta-Appliken aus Tarent (7 Erg. RM); FH Kerle: Heidelberg, Germany, 1962; p. 74, tav. 17.

6. De Juliis, E. Gli ori di Taranto in età Ellenistica (Catalogo Della Mostra di Milano); Mondadori: Milano, Italy, 1984; p. 393.

7. Godart, L.; De Caro, S. (Eds.) Nostoi: Capolavori Ritrovati; catalogo della mostra, Roma, Quirinale, 23 marzo-20 maggio 2007; Segretariato generale della presidenza della Repubblica: Roma, Italy, 2007.

8. Pellegrini, M. Intrigo Internazionale. In Archeo; Timeline Publishing srl: Roma, Italy, 2016; p. 375.

9. Isman, F. I Predatori Dell'arte perduta. Il Saccheggio Dell'archeologia in Italia; Skira: Milano, Italy, 2009.

10. The Museum Complex of Ascoli Satriano. Available online: http://polomusealeascolisatriano.blogspot.it/ (accessed on 15 April 2020).

11. Cozzolino, M.; Di Giovanni, E.; Mauriello, P.; Piro, S.; Zamuner, D. Geophysical Methods for Cultural Heritage Management; Springer: Cham, Switzerland, 2018. [CrossRef]

12. Brizzolari, E.; Cardarelli, E.; Piro, S.; Versino, L. Detection of subsurface magnetic anomalies of archaeological interest: Computation of tridimensional magnetic anomalies and interpretation using bidimensional cross-correlation. TPAG 1993, 7, 3-16.

13. Fassbinder, J.W.E.; Reindel, M. Magnetometer prospection as research for pre-Spanish cultures at Nasca and Palpa, Perù. In Proceedings of the 6th International Archaeological Prospection Conference, Rome, Italy, 14-17 September 2005; Piro, S., Ed.; CNR: Roma, Italy, 2005; pp. 6-10.

14. Scollar, I. Electromagnetic Prospecting Methods in Archaeology. Archaeometry 1962, 5, 146-153. [CrossRef]

15. Tabbagh, A. Applications and Advantages of the Slingram Electromagnetic Method for Archaeological Prospecting. Geophysics 1986, 51, 576-584. [CrossRef]

16. Tsokas, G.N.; Giannopoulos, A.; Tsourlos, P.; Vargemezis, G.; Tealby, J.M.; Sarris, A.; Papazachos, C.B.; Savopoulou, T. A large scale geophysical survey in the archaeological site of Europos (northern Greece). J. Appl. Geophys. 1994, 32, 85-98. [CrossRef]

17. Papadopoulos, N.G.; Tsourlos, P.; Tsokas, G.N.; Sarris, A. Two-dimensional and three-dimensional resistivity imaging in archaeological site investigation. Archaeol. Prospect. 2006, 13, 163-181. [CrossRef]

18. Compare, V.; Cozzolino, M.; Mauriello, P.; Patella, D. 3D Resistivity probability tomography at the prehistoric site of Grotta Reali (Molise, Italy). Archaeol. Prospect. 2009, 16, 53-63. [CrossRef]

19. Compare, V.; Cozzolino, M.; Mauriello, P.; Patella, D. Resistivity Probability Tomography Imaging at the Castle of Zena, Italy. EURASIP J. Image Video Process. 2009, 2009, 1-9. [CrossRef]

20. Minelli, A.; Cozzolino, M.; Di Nucci, A.; Guglielmi, S.; Giannantonio, M.; D’Amore, D.; Pittoni, E.; Groot, A.M. The prehistory of the Colombian territory: The results of the Italian archaeological investigation on the Checua site (Municipality of Nemocòn, Cundinamarca Department). J. Biol. Res. 2012, 85, 94-97. [CrossRef]

21. Cozzolino, M.; Mauriello, P.; Patella, D. Resistivity Tomography Imaging of the substratum of the Bedestan Monumental Complex at Nicosia, Cyprus. Archaeometry 2014, 56, 331-350. [CrossRef]

22. Cozzolino, M.; Di Giovanni, E.; Mauriello, P.; Vanni Desideri, A.; Patella, D. Resistivity tomography in the Park of Pratolino at Vaglia (Florence, Italy). Archaeol. Prospect. 2012, 19, 253-260. [CrossRef]

23. Lentini, M.C.; Pakkanen, J.; Sarris, A. Naxos of Sicily in the 5th Century BC: New Research. In Greek Colonization. New Data, Current Approaches, Proceedings of the Scientific Meeting Held in Thessaloniki, Thessaloniki, Greece, 6 February 2015; Veleni, P., Tsagari, D., Eds.; Alpha Bank: Athens, Greece, 2015; pp. 23-35.

24. Cozzolino, M.; Longo, F.; Pizzano, N.; Rizzo, M.L.; Voza, O.; Amato, V. Multidisciplinary Approach to the Study of the Temple of Athena in Poseidonia-Paestum (Southern Italy): New Geomorphological, Geophysical and Archaeological Data. Geosciences 2019, 9, 324. [CrossRef]

25. Cozzolino, M.; Caliò, L.M.; Gentile, V.; Mauriello, P.; Di Meo, A. The Discovery of the Theater of Akragas (Valley of Temples, Agrigento, Italy): An Archaeological Confirmation of the Supposed Buried Structures from a Geophysical Survey. Geosciences 2020, 10, 161. [CrossRef]

26. Goodman, D.; Nishimura, Y. A Ground-radar view of Japanese burial mounds. Antiquity 1993, 67, 349-354. [CrossRef]

27. Nishimura, Y.D.; Goodman, D. Ground-penetrating radar survey at Wroxeter. Archaeol. Prospect. 2000, 7, 101-105. [CrossRef]

28. Amato, V.; Cozzolino, M.; De Benedittis, G.; Di Paola, G.; Gentile, V.; Giordano, C.; Marino, P.; Rosskopf, C.M.; Valente, E. An integrated quantitative approach to assess the archaeological heritage in highly anthropized areas: The case study of Aesernia (southern Italy). Acta IMECO 2016, 5, 33-43. [CrossRef] 
29. Cozzolino, M.; Baković, M.; Borovinić, N.; Galli, G.; Gentile, V.; Jabučanin, M.; Mauriello, P.; Merola, P.; Živanović, M. The contribution of geophysics to the knowledge of the hidden archaeological heritage of Montenegro. Geoscience 2020, 10, 187. [CrossRef]

30. Cozzolino, M.; Gentile, V.; Giordano, C.; Mauriello, P. Imaging buried archaeological features through Ground Penetrating Radar: The case of the ancient Saepinum (Campobasso, Italy). Geoscience 2020, 10, 225. [CrossRef]

31. Avdelidis, N.P.; Moropoulou, A. Applications of infrared thermography for the investigation of historic structures. J. Cult. Heritage 2004, 5, 119-127. [CrossRef]

32. Burrows, S.E.; Rashed, A.; Almond, D.P.; Dixon, S. Combined laser spot imaging thermography and ultrasonic measurements for crack detection. Nondestruct. Test. Eval. 2007, 22, 217-227. [CrossRef]

33. Kandemir-Yucel, A.; Tavukcuoglu, A.; Caner-Saltik, E.N. In situ assessment of structural timber elements of a historic building by infrared thermography and ultrasonic velocity. Infrared Phys. Technol. 2007, 49, 243-248. [CrossRef]

34. Bavusi, M.; Soldovieri, F.; Piscitelli, S.; Loperte, A.; Vallianatos, F.; Soupios, P. Ground penetrating radar and microwave tomography to evaluate the crack and joint geometry in historical buildings: Some examples from Chania, Crete, Greece. Near Surf. Geophys. 2010, 8, 377-387. [CrossRef]

35. Candoré, J.C.; Bodnar, J.L.; Detalle, V.; Grossel, P. Non-destructive testing in situ, of works of art by stimulated infrared thermography. J. Phys. Conf. Ser. 2010, 214, 012068. [CrossRef]

36. Danese, M.; Demšar, U.; Masini, N.; Charlton, M. Investigating material decay of historic buildings using visual analytics with multi-temporal infrared thermographic data. Archaeometry 2010, 52, 482-501. [CrossRef]

37. Carlomagno, G.M.; Di Maio, R.; Fedi, M.; Meola, C. Integration of infrared thermography and highfrequency electromagnetic methods in archaeological surveys. J. Geophys. Eng. 2011, 8, 93-105. [CrossRef]

38. Leucci, G.; Masini, N.; Persico, R.; Soldovieri, F. GPR and sonic tomography for structural restoration: The case of the cathedral of Tricarico. J. Geophys. Eng. 2011, 8, 76-92. [CrossRef]

39. Sambuelli, L.; Bhom, G.; Capizzi, P.; Cardarelli, E.; Cosentino, P. Comparison between GPR measurements and ultrasonic tomography with different inversion algorithms: An application to the base of an ancient Egyptian sculpture. J. Geophys. Eng. 2011, 8, 106-116. [CrossRef]

40. Bodnar, L.; Candoré, J.C.; Nicolas, J.L.; Szatanik, G.; Detalle, V.; Vallet, J.M. Stimulated infrared thermography applied to help restoring mural paintings. J. NDT E Int. 2012, 49, 40-46. [CrossRef]

41. Knudson, D.L.; Rempe, J.L. Linear Variable Differential Transformer (LVDT)-based elongation Measurements in Advanced Test Reactor high temperature irradiation testing. Meas. Sci. Technol. 2012, 23, 025604. [CrossRef]

42. Alani, A.M.; Aboutalebi, M.; Kilic, G. Applications of ground penetrating radar (GPR) in bridge deck monitoring and assessment. J. Appl. Geophys. 2013, 97, 45-54. [CrossRef]

43. Kadioglu, S.; Kadioglu, Y.K.; Catapano, I.; Soldovieri, F. Ground penetrating radar and microwave tomography for the safety management of a cultural heritage site: Miletos Ilyas Bey Mosque (Turkey). J. Geophys. Eng. 2013, 10, 064007. [CrossRef]

44. Catapano, I.; Gennarelli, G.; Ludeno, G.; Soldovieri, F. Applying Ground-Penetrating Radar and Microwave Tomography Data Processing in Cultural Heritage: State of the art and future trends. IEEE Signal. Process. Mag. 2019, 36, 53-61. [CrossRef]

45. Arias, P.; Armesto, J.; Di-Capua, D.; González-Drigo, R.; Lorenzo, H.; Pérez-Gracia, V. Digital photogrammetry, GPR and computational analysis of structural damages in a mediaeval bridge. Eng. Fail. Anal. 2007, 14, 1444-1457. [CrossRef]

46. Oses, N.; Dornaika, F.; Moujahid, A. Image-based delineation and classification of built heritage masonry. Remote Sens. 2014, 6, 1863-1889. [CrossRef]

47. Costanzo, A.; Minasi, M.; Casula, G.; Musacchio, M.; Buongiorno, M.F. Combined use of terrestrial laser scanning and IR thermography applied to a historical building. Sensor 2015, 15, 194-213. [CrossRef]

48. Barrile, V.; Bilotta, G.; Meduri, G.M.; De Carlo, D.; Nunnari, A. Laser Scanner technology, ground-penetrating radar and augmented reality for the survey and recovery of the artistic, archaeological and cultural heritage. ISPRS Ann. Photogramm. Remote Sens. Spat. Inf. Sci. 2017, 123-127. [CrossRef]

49. Danese, M.; Sileo, M.; Masini, M. Geophysical Methods and Spatial Information for the Analysis of Decay frescoes. Surv. Geophys. 2018, 6, 1149-1166. [CrossRef] 
50. Cozzolino, M.; Gabrielli, R.; Galatà, P.; Gentile, V.; Greco, G.; Scopinaro, E. Combined use of 3D metric surveys and non-invasive geophysical surveys for the determination of the state of conservation of the Stylite Tower (Umm ar-Rasas, Jordan). Ann. Geophys. 2019, 61, 72. [CrossRef]

51. Cozzolino, M.; Di Meo, A.; Gentile, V. The contribution of indirect topographic surveys (photogrammetry and the laser scanner) and GPR investigations in the study of the vulnerability of the Abbey of Santa Maria a Mare, Tremiti Islands (Italy). Ann. Geophys. 2019, 61, 71. [CrossRef]

52. Remondino, F.; El-Hakim, S. Image-based 3-D modelling: A review. Photogramm. Rec. 2006, 21, $269-291$. [CrossRef]

53. Remondino, F.; El-Hakim, S.F.; Gruen, A.; Zhang, L. Turning images into 3-D models. IEEE Signal Process. Mag. 2008, 25, 55-65. [CrossRef]

54. Angelini, A.; Portarena, D. Advice for archaeological survey with recent technologies. Acta IMEKO 2018, 7, 42-51. [CrossRef]

55. GPR-SLICE Software. Available online: http://www.gprsurvey.com/practice/GPR-SLICE (accessed on 15 March 2020).

56. Jol, H. Ground Penetrating Radar: Theory and Applications; Elsevier: Amsterdam, The Netherlands, 2009.

57. Evans, R.D. Optimising Ground Penetrating Radar (GPR) to Assess Pavements. Ph.D. Thesis, Loughborough University, Loughborough, UK, August 2009.

58. Conyers, L.B.; Goodman, B. Ground-Penetrating Radar: An Introduction for Archaeologists; AltaMira Press: Walnut Creek, CA, USA; London, UK; New Delhi, India, 1997; p. 232.

(C) 2020 by the authors. Licensee MDPI, Basel, Switzerland. This article is an open access article distributed under the terms and conditions of the Creative Commons Attribution (CC BY) license (http://creativecommons.org/licenses/by/4.0/). 